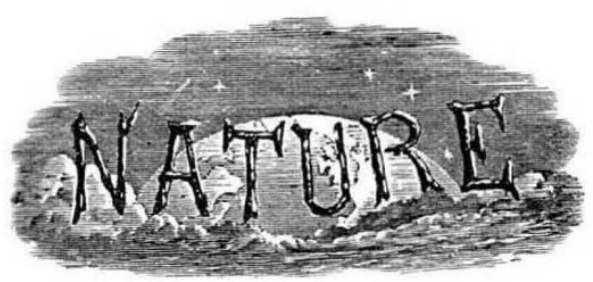

SATURDAY, MARCH 26, 1932

\begin{tabular}{|c|c|c|c|c|}
\hline \multicolumn{4}{|l|}{ CONTENTS } & PAGE \\
\hline Biology in the Schools. By J. R. . & & & . & \\
\hline Can Nature be Explained ? By Austin D & uncan & -Jon & & 452 \\
\hline Colour Standardisation. By J. Guild & & & . & 453 \\
\hline Amalie Dietrich, Naturalist. By J. S. G. & & & . & 455 \\
\hline hort Reviews & . & & . & 455 \\
\hline $\begin{array}{l}\text { rigin of the Gamma Rays. By the } \\
\text { Lord Rutherford, O.M., F.R.S. }\end{array}$ & Right & Ho & & 457 \\
\hline Index Londinensis . . . . . & . & & & 459 \\
\hline Atmospheric Pollution. By H. J. Hodsn & nan, $\mathbf{M}$ & I.B.E & & 460 \\
\hline $\begin{array}{l}\text { bituary : } \\
\text { Dr. E. H. Griffiths, F.R.S. By Sir Ri }\end{array}$ & & & & \\
\hline , K.C.B., F.R.S. & . & & - & 461 \\
\hline ws and Views . . . & . & . & & 462 \\
\hline Ohation & & & & \\
\hline $\begin{array}{l}\text { bservations of } \mathrm{Infr} \\
\text { Spectrum.-Prof. I }\end{array}$ & & & & \\
\hline Origin of the Coronal Lines.-Dr. T. & L. de & Bru & & 468 \\
\hline $\begin{array}{l}\text { Passage of Neutrons through } \\
\text { H. S. W. Massey . }\end{array}$ & & & & 46 \\
\hline Radioactive Disintegration and Nuc & clear $\mathrm{S}_{1}$ & Spin. & & \\
\hline 'ruicture of Polveacct & 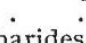 & $\approx$ & & 470 \\
\hline ne, C.B.E., F.R.S. & & & & \\
\hline $\begin{array}{l}\text { Vertical Tube Counter- and the } \\
\text { Effect of Cosmic Radiation at Sea- }\end{array}$ & & & & \\
\hline & & & & 471 \\
\hline $\begin{array}{l}\text { Molecular Refraction of Nitrobenz } \\
\text { Newton Friend }\end{array}$ & & & & 471 \\
\hline icture of the Mercury & Line 54 & 471 & & \\
\hline ers.-Dr. N. I & & & & $\begin{array}{l}472 \\
473\end{array}$ \\
\hline ebrates.-F. & & & & \\
\hline in Age-_Laurie & $\mathrm{Ma}$ & & & 473 \\
\hline$\cdot \quad \cdot \quad \cdot$ & $\cdot$ & & & 474 \\
\hline mical Topics . . & . & & & 476 \\
\hline Atomic Weights . & . & & & 477 \\
\hline heries Investigations & . & & & 477 \\
\hline d and Tobago & . & . & . & 478 \\
\hline al Heresies . . . . . & . & . & . & 479 \\
\hline ngress of Prehistoric & and & Pro & & \\
\hline & . & - & & 479 \\
\hline ucational Intelligence & . & . & & 480 \\
\hline al Exploration & . & . & & 481 \\
\hline ademies . . . & . & - & & 481 \\
\hline & . & • & & 484 \\
\hline eivec & . & & & 484 \\
\hline chnical Books & . & . & & \\
\hline
\end{tabular}

Editorial and Publishing Offices:

MACMILLAN \& CO., LTD.

ST. MARTIN'S STREET, LONDON, W.C. 2

Editorial communications should be addressed to the Editor Advertisements and business letters to the Publishers

Telephone Number: GERRARD 8830

Telegraphic Address: PHUSIS, WESTRAND, LONDON No. 3256, VoL. 129]

\section{Biology in the Schools}

$\triangle$ PART altogether from the importance of 11 biology as a vocational study-biology for bread-upon which the Chelmsford Report laid emphasis (Nature, Feb. 20, p. 257), there is the wider and more humane aspect of biology as an appreciation of the unity of living things, and therefore as the link between the individual and all his environment-biology for life.

Why is it that the value of this appreciation, as something that adds interest to life and has a social value as well as an intellectual, has not been sufficient to compel the inclusion of biology in the work of the schoolroom? Of its definite exclusion from the school there can be no doubt, in spite of the exceptions which emphasise the rule. Nothing could be more encouraging to the enthusiastic biologist than, say, last year's annual reports of the work done by the natural history societies at Eton, Marlborough, and a few other schools; they show a grasp of the possibilities of Nature study, an appreciation of the zest of discovering new things, and, above all, an intense keenness in this branch of study which combines learning with investigation. But these are shining lights ; the vast majority of the children of Great Britain walk in biological darkness: to them the opportunity of this ever-fresh interest is denied. Of eighty-six medical students going to one of our northern universities this winter for the first time, six had learned a little botany, the others had neither botany, zoology, nor biology-a measure of the lack of biological teaching in the schools of the north, and probably the condition is repeated, though, we trust, not so decisively, in other regions of the kingdom.

One of the deciding factors in the area we refer to is the exclusion of biology and related sciences from the subjects for proficiency in which competition bursaries are awarded. The bursary competition enforces a trend of curriculum in the schools as inevitably as the scholarship examinations and awards at Oxford and Cambridge have been found by the Chelmsford Committee to enforce over-specialisation within a limited range of subjects.

A second deciding factor against biology as a school subject has been the well-entrenched position of physics and chemistry in the curriculum as representative of the observational sciences. With this may be associated the fact that it is probably easier to devise a suitable observational and experimental course with inanimate material than 
with living organisms, and consequently that the proper teaching of biology is more difficult and the supply of adequately trained teachers much more restricted.

These factors lie outside the direct influence of the biologist, but the third factor which has hindered the adoption of biology in the schools lies with the biologists themselves-they have failed to give a decided lead as to what biology in the schools is to connote. It is regarded as a vague term, covering a multitude of ill-defined interests, or it is looked upon as simply a little botany plus a little zoology, each almost or altogether isolated in its own compartment. Within the last year or two, many books devised for the teaching of biology in schools have been published, and their variety in range, in subject matter, and in treatment shows how earnest an endeavour is being made to meet the demand for guidance; but at the same time it exposes the difficulty with which the willing but less experienced teacher is faced when he has to choose between so many possibilities.

We would be the last to suggest that a formal and set course in biology should be imposed upon such schools as desire the subject, for it is one of the attractive features of biology that it can and should adapt itself to the special environment of each locality. But we do say that now is the time for indicating the content of biology as best fitted for the interests of pupils in schools, and of giving a skeleton form to a subject which to many appears to be so vague as to be almost formless. Otherwise, how can it be expected that school managers or governors, unacquainted with the subject at first hand, will be able honestly to decide that here is a branch of science eminently suited and highly desirable for inclusion in the curricula of the schools under their care.

In the devising of such a course, which is to influence and appeal to a vast majority of pupils who will never enter a university or apply biology professionally, the constant aim must be biology for its interest, its outlook, and its understanding'biology for life'.

The problem of the biology course is not confined to Great Britain. For twenty years and more the subject has been taught in the high schools of the United States of America, and so long ago as 1905 the State of New York issued its first syllabus in biology. The result was definite and encouraging, for work in the new field developed rapidly and met with unusual success. It was accompanied by an increasing desire to keep the science teaching in the schools in touch with the experi. ence of the pupil in his own environment, and there followed the State's syllabus in general science in 1925. On this a broad foundation of scientific knowledge has been laid, and it is testimony to skilful planning that in its turn the growing emphasis upon the work in general science has demanded a further step in evolution, and that is the development of a broad course in general biology to cap the training in general science.

This new course, the substance of which has just been published,* is the result of a year and a half of consideration by a committee of science teachers and educationists selected for the purpose. It aims at rounding off the science training of the schools by bringing within the range of the many adolescents in the secondary schools the larger conceptions of biology; therefore it presupposes the existence of an earlier training of one to three years in general science. It is worth while con. sidering the nature of this foundational training, for upon its soundness the fate of the edifice must rest.

There is universal agreement, the committee states, that the preparatory general science should deal with the environment, and should centre about the pupil as the interested focus of his or her environment. "General science should not consist of a succession of physical, chemical, biological, astronomical, and similar topics presented chiefly as a survey of these different sciences. The purpose of general science is not to acquaint the pupil with the various sciences as entities in themselves," . . . but to lead him "to investigate as an individual the various phases of the environ. ment as they impose themselves upon him."

That seems to be a simple limitation, but it is far from being so simple as it looks; and accordingly it has been found that the teacher, perhaps following his own bent rather than the child's, perhaps because it is easier, has often strayed much further into, say, the "practical and mechanical application of physical principles and into the abstract underlying laws than is justified by the attitude of enquiry on the part of the pupil". Nevertheless, the rule is that general science in its early stages should deal with immediate environment, and that every lesson should start off from the outlook of the pupil, with all its limitations and immaturities-that is sound teaching, which should lead the pupil gently into varied fields of chemistry, physics, and simple biology.

* Tentative Syllabus in General Biology, published by the University of the State of New York: Albany, 1931. Pp. 62.

No. 3256, VoL. 129] 
On ground thus prepared, the course of general biology is to be laid. It opens and it closes with man in the centre of the picture, played upon by, and in turn playing upon, his environment. The reason for the prominence given to human relations is that studies organised with their focus upon humanity will prove to be psychologically most interesting to the pupils. We do not feel convinced that the insistence at this stage upon the dominance of human contacts is essential, since the interest of the majority of pupils at the age contemplated is easily held by the study of any living thing. But few will cavil at the guiding principles of interest and largest social value which have determined the actual selection and arrangement of the content of the course, or at the endeavour of the committee to arrange the material in a sequence of "dependent continuity and ascending difficulty".

The programme for the course of general biology falls into four sections, divided into two partsapparently for the convenience of the teaching year, for there is no real discontinuity between the two. The first section deals with "man's place in the world of living things ", and the breadth of the treatment is indicated, but only roughly, by the three themes (each to occupy about three weeks of school time) round about which the lessons are grouped-" Man is one species among millions of diverse species"; "There is unity among all living things"; "Living things and their environment are constantly changing". From simple observation, comparison, and identification of types of plants and animals, and the recognition of diversity of form, the pupil is led to inquire into the significance of similarities and differences; and having associated changes in environment with changes in organisms, he is drawn by inductive methods to the acceptance of evolution as the simplest explanation of these phenomena.

"Self-preservation among living things" is the general subject of the second section, with three supporting themes-" All living things have the same problems"; "Living things bear different nutritional relations to their environment"; and "Living things have to relate themselves to their environment". The section begins with a study of the activities of single-celled organisms, and of the specialisation which these activities and their associated structures undergo in multi-cellular organisms; nutritional activities are selected for special discussion; and this leads to consideration of the contacts with environment made by the organism through sensation and response.
The topic of self-preservation is followed, in section three, by that of "Race-preservation among living things", and this gives opportunity for a comparative study of reproductive methods, leading to consideration of the cell-basis of reproduction and so to the cell in heredity, to the outlines of plant and animal breeding, and of inheritance in mankind.

In the final section, entitled "Man's increasing control over his environment and over himself", a wide range of possibilities lies before the teacher, for there must be considered typical ways in which environment is 'improved', say, by cultivation and by warfare against other organisms which are inimical to human welfare, and so to the balance of Nature and its unstable equilibrium. Last of all is traced the progress of man as a biological phenomenon, with a unique and accumulating social heritage, and a slow development from the eolith-maker to the time when the domestication of animals hastened the pace towards the scientific age, at the beginning of which we stand to-day.

In the consideration of this ambitious scheme of biological teaching for the secondary school, several important facts must be borne in mind. In the first place, the syllabus, which in the above summary must appear to be despairingly vague to the teacher who longs for a prescribed course of details, has been deliberately denuded of factual content, so that the teacher himself, keeping in view the emphasis upon great biological truths, may adapt the lessons to the particular needs of the urban or rural district in which he is placed. Many hints as to possible modes of treatment are given in the 62 pages of the "Syllabus". In the second place, the syllabus does not stand by itself, but is correlated with an earlier body of general scientific knowledge, and the general biology course is to be succeeded by detailed work in the sciences of chemistry and physics. In the third place, the syllabus is regarded as suggestive rather than final, and it is accompanied by a request to teachers for constructive criticism.

Even before the syllabus meets the test of actual trial, however, it will be recognised that the Committee has done a useful work in emphasising the close relationship between biology and the social sciences, and in making a determined step towards the creation of a co-ordinated programme of science tuition which will endow pupils about to leave the upper schools with the broadest values likely to be obtained by the application of the scientific method.
J. R.

$$
\text { No. 3256, VoL. 129] }
$$

